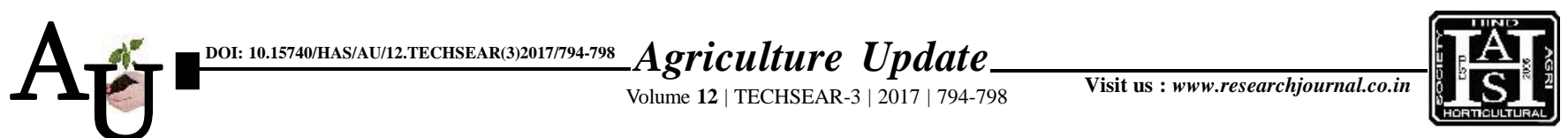

D e ISSN-0976-6847

\title{
Research Article: Mass multiplication of Beauveria bassiana on substrates
}

\section{P. SWATHI, S.B. DAS AND P.N. GANGA VISALAKSHY}

Article Chronicle :

Received :

13.07.2017;

Accepted :

28.07.2017

KEY Words:

Substrates, Beauveria bassiana, Spore load, Production cost

Author for correspondence :

\section{P. SWATHI}

Department of

Entomology, Jawaharlal

Nehru Krishi Vishwa

Vidyalaya, JABALPUR

(M.P.) INDIA

Email :

padavalaswathi107@

gmail.com

See end of the article for

authors' affiliations
SUMMARY : Different solid substrates viz. sorghum, maize, chickpea, ragi,rice and Neem cakeand liquid media's viz., potato dextrose broth(PDB), czapek dox broth (CDB) and sabouraud dextrose broth (SDB) were evaluated for mass multiplication of Beauveria bassiana (Balsamo) Vuillemin. Rice $\left(\mathrm{T}_{5}\right)$ were found to be best and exhibited maximum population $\left(8.78 \times 10^{8} \mathrm{cfu} / \mathrm{ml}\right)$ followed by PDB $\left(\mathrm{T}_{7}\right)$ with $7.44 \times 10^{8} \mathrm{cfu} / \mathrm{ml}$. And significantly lowest production cost was recorded in rice $\left(\mathrm{T}_{5}\right)($ Rs. 1.01).

How to cite this article : Swathi, P., Das, S.B. and Visalakshy, P.N. Ganga (2017). Mass multiplication of Beauveria bassiana on substrates. Agric. Update, 12(TECHSEAR-3) : 794-798; DOI: 10.15740/HAS/AU/ 12.TECHSEAR(3)2017/794-798. 